\title{
Addition of anacardic acid as antioxidants in broiler chicken mortadella
}

\author{
Virgínia Kelly Gonçalves ABREU ${ }^{1}$, Ana Lúcia Fernandes PEREIRA ${ }^{1 \star}$, Ednardo Rodrigues de FREITAS², \\ Maria Teresa Salles TREVISAN ${ }^{3}$, José Maria Correia da COSTA ${ }^{4}$
}

\begin{abstract}
The effect of anacardic acid on lipid stability and coloration of chicken mortadella was investigated. Antioxidants were added to chicken mortadellas, according to the treatments: no added antioxidant, $100 \mathrm{ppm}$ butylated hydroxytoluene and 50, 100, 150 and $200 \mathrm{ppm}$ anacardic acid. The mortadellas were stored for 90 days at $4{ }^{\circ} \mathrm{C}$, and the analysis of lipid oxidation and color were performed. For TBARS, there was linear reduction with increased anacardic acid. According to the means test, $200 \mathrm{ppm}$ anacardic acid provided the lower TBARS values. The redness decreased during storage, and, as reported by the means test, mortadella containing $200 \mathrm{ppm}$ anacardic acid had lower values. The lightness of mortadellas decreased during storage. Also in accordance with the means test, mortadellas containing antioxidants had same lightness than control. The yellowness of mortadellas increased during storage. Thus, the anacardic acid is a potential natural antioxidant that could be included in chicken mortadella formulations before cooking.
\end{abstract}

Keywords: natural antioxidant; lipid oxidation; redness; yellowness; lightness; storage.

Practical Application: This paper is the first about the application of anacardic acid in a meat product.

\section{Introduction}

Chicken meat contains relatively high amounts of unsaturated fatty acids, which increases the concerns regarding oxidative deterioration. This oxidation often determines the shelf life of pre-cooked, chilled and ready-to-eat products made from chicken meat (Xiao et al., 2011).

The mortadella is a meat product present in a great proportion of the human diet. The flavour, colour and taste play a decisive role in consumer acceptance. This meat product is made from an emulsion of meats of one or more species of animal butchery, which incorporates small cubes of delicately flavoured pork fat. Changes in the sensory attributes of mortadella could be due to the rancidity. Lipid oxidation is a chemical phenomenon that cannot be avoided during the storage of meat products, but it can be diminished by adding antioxidant substances that provide more stability and avoid the rancidity of the fat (Brasil, 2000; Berasategi et al., 2011; Doménech-Asensi et al., 2013).

Synthetic antioxidants, butylhydroxy anisole (BHA), butylhydroxy toluene (BHT), and sodium citrate, have been proved to be eficient and needed for stabilizing meat products rich in unsaturated fatty acids (Lee et al., 2006; Valencia et al., 2007). However, toxicological studies have demonstrated the ability of these antioxidants present carcinogenic effect in experiments with animals. In other studies, BHA was found to induce gastrointestinal hyperplasia in rodents by a mechanism unknown (Botterweck et al., 2000; Cruces-Blanco et al., 1999).
Thus, due to health risks associated with its use and the better perception of natural products by consumers, the use of different plant extracts (fruits, vegetables, spices, herbs and seeds), with antioxidant activity is being under research. The grape residue extracts were successfully applied to reduce fat deterioration in raw and cooked chicken meat during frozen storage (Selani et al., 2011). Kanatt et al. (2010) reduced the formation of 2-thiobarbituric acid reactive substances in chicken products by using pomegranate peel extract.

Anacardium occidentale L. (cashew), an important member of the family Anacardiaceae, is a tropical tree originally indigenous to Brazil. The cashew apple is very juicy, fibrous and also edible and thus the plant has a commercial value. Moreover, the cashew nut shell liquid (CNSL) is an important agricultural by-product of cashew nut production, and chemical analysis on CNSL showed the presence of a high amount of anacardic acids. The anacardic acids are phenolic compounds biosynthesized from fatty acids and account for about $90 \%$ of the composition of the liquid extracted from CNSL, which is also found in smaller proportions in the stalk and nuts (Hemshekhar et al., 2012; Morais et al., 2010).

A number of biological activities has been discovered for anacardic acids, including the antioxidant activity (Correia et al., 2006). Trevisan et al. (2006), when analyzing the antioxidant capacity of anacardic acids, cardanols and cardols present in the cashew apple, nuts and CNSL, noted that anacardic acids have higher antioxidant capacity when compared to cardols and cardanols. For the toxicological aspect of the anacardic acids, Carvalho et al. (2011) evaluated the acute, subacute toxicity and mutagenic 
effects of anacardic acids from cashew in mice. These authors, concluded that doses less than $300 \mathrm{ppm}$ (parts per million) did not produce biochemical and hematological alterations in mice.

Abreu et al. (2014) evaluated the effect of anacardic acid on oxidative and color stability of spray dried egg yolk using dose up to $200 \mathrm{ppm}$. The results indicated that the dose of $150 \mathrm{ppm}$ anacardic acid had the best results among treatments studied to prevent the damage of lipid oxidation in the yolk, favoring the coloring. However, there are no reports on its performance when applied to meat products. Therefore, the aim of the present study was to evaluate the effect of anacardic acid on lipid stability and coloring of chicken mortadellas stored for 90 days.

\section{Materials and methods}

In the present study were used broiler thigh and drumstick of commercial lineage from Poultry Sector of Department for Animal Science, Federal University of Ceará, fed on a standard diet. The broilers were slaughtered at 42 days of age.

\subsection{Extraction and purification of anacardic}

The purification of anacardic acid from CNSL was performed as described by Paramashivappa et al. (2001). The cashew nuts used to obtain the calcium anacardate were from cashews harvested in Paraipaba, Ceará, Brazil, at 2011. The fruits were from a commercial cultivation (CCP-76), whose genetic material is kept in germplasm bank of Embrapa Agroindústria Tropical. The cashew nut shell liquid (CNSL) was extracted by the Organic and Inorganic Chemistry Department of Federal University of Ceará. Briefly, anacardic acids were isolated from CNSL in the form of their calcium salts. The calcium anacardate was suspended in water and hydrochloric acid, and the resulting solution extracted with ethyl acetate. The resulting organic fraction was then concentrated to obtain the anacardic acid.

\subsection{Experimental design}

The experiment followed a complete randomized factorial ( 6 treatments and 4 storage times), with five replicates per treatment on each storage time, totaling 120 observations. The antioxidants were added in the mortadellas in accordance with the treatments: without the addition of antioxidant (control) and with addition of $100 \mathrm{ppm}$ of the BHT (butylated hydroxytoluene) synthetic antioxidant; with addition of 50, 100, 150 and $200 \mathrm{ppm}$ of anacardic acid (AA). After preparation, the chicken mortadellas were stored for 90 days, and analyzed with $0,30,60$ and 90 days.

\subsection{Production of chicken mortadella}

The chicken mortadella samples weighing $100 \pm 0.01 \mathrm{~g}$ were prepared by mixing the ingredients described in Table 1 . The skin and bones of thigh and drumsticks were manually removed. The resulting of chicken meat and back fat was minced once in a model (Vicris 2524, Sao Paulo, Brazil) through a plate with holes of $0.8 \mathrm{~cm}$ diameter. For each mortadella batch (it were made 30 batches), minced chicken meat was placed in a cutter (Cut.4, Brusque, Brazil) and blended with all ingredients. The final meat batter temperature was $8{ }^{\circ} \mathrm{C}$. Each batch of mixture obtained (mixture of meat and all ingredients) was then filled into $40 \mathrm{~mm}$ synthetic casings and cooked in a water bath (Tecnal TE 057, Piracicaba, Brazil) at $80^{\circ} \mathrm{C}$ to an internal temperature of $78^{\circ} \mathrm{C}$. The mortadellas were then chilled in an iced/water bath until an internal temperature of $25^{\circ} \mathrm{C}$. The product temperature was registered throughout the process with an insertion thermometer (Delt DT 700, Sao Paulo, Brazil). The mortadella samples extract were then stored at $4{ }^{\circ} \mathrm{C}$ for 90 days.

\subsection{Lipid oxidative determination}

Lipid oxidation was evaluated by determining the thiobarbituric acid reactive substances (TBARS) using the aqueous acid extraction method according to the technique described by Cherian et al. (2002). It were weighed $2 \mathrm{~g}$ of mortadella samples, being then homogenized with $18 \mathrm{~mL}$ of perchloric acid $(3.86 \%$ aqueous solution) and $50 \mu \mathrm{L}$ BHT (4.5\% ethanol solution). The homogenate was filtered and $2 \mathrm{~mL}$ were transferred to tubes with $2 \mathrm{~mL}$ of 2-thiobarbituric acid ( $20 \mathrm{mM}$ aqueous solution). Thereafter, the tubes were heated in thermo-regulator bath at $100^{\circ} \mathrm{C}$ for 30 minutes. The pink color produced by the reaction between the malonaldehyde and 2-thiobarbituric acid was measured by spectrophotometer at $531 \mathrm{~nm}$ (Biospectro, SP-22, Curitiba, Brazil). The TBARS in the samples were expressed as mg malonaldehyde per kg mortadella.

\subsection{Colorimeter measurements}

The objective measurement of the mortadella samples color was performed by Minolta CR300 colorimeter, Tokyo, operating in the system $\operatorname{CIE}\left(\mathrm{L}^{*}, \mathrm{a}^{*}\right.$ and $\left.\mathrm{b}^{*}\right)$, with the apparatus calibration performed by white ceramic plate, using the D65 illuminant. The measurements were made on the surface of the product immediately after cutting mortadellas into $1 \mathrm{~cm}$ thick slices.

\subsection{Statistical analysis}

Statistical analyses were performed using the Statistical Analysis System (SAS, version 9.2) at 5\% probability for significance. Initially, data were subjected to analysis of variance according

Table 1. Formulation of chicken mortadellas containing synthetic antioxidant (butylated hydroxytoluene) or anacardic acid (AA).

\begin{tabular}{lc}
\hline \multicolumn{1}{c}{ Meat componentes } & $\%$ \\
\hline Thigh and drumsticks & 85.00 \\
Back fat & 15.00 \\
Ingredients and additives & $\%$ of meat \\
Iced-water & 10.00 \\
Starch & 5.00 \\
Sodium chloride & 1.10 \\
Mortadella condiment $^{1}$ & 1.00 \\
Cured salt $^{2}$ & 0.30 \\
Garlic & 0.30 \\
Antioxidant & ${ }^{3}$ \\
Sodium tripolyphosphate & BHT or AA \\
Spices & 0.25 \\
\hline
\end{tabular}

${ }^{1}$ Refined sodium chloride and natural flavoring. ${ }^{2}$ Refined sodium chloride, sodium nitrite (INS 250) and sodium nitrate (INS 251). ${ }^{3}$ Not added in the samples of control treatment. 
to a factorial design, which included the effects of treatment, storage time and the interaction between treatment and storage time. When significant interaction was verified, there was the unfolding to evaluate the effect of each factor in relation to the other. To compare the results among all treatments, it was performed the means comparison by the Student-Newman-Keuls test (SNK). In addition, a regression analysis was performed to describe the effect of storage time and dose of anacardic acid added to the mortadellas; in the latter the data obtained with the BHT addition were removed from the analysis.

\section{Results and discussion}

\subsection{Evaluation of lipid oxidation during shelf-life storage}

In this study, there was no significant interaction ( $\mathrm{p}>0.05)$ between treatments and storage times of mortadellas for TBARS values (Table 2). According to the regression analysis, the TBARS values also did not vary significantly ( $\mathrm{p}>0.05)$ during storage. However, there was a linear reduction in these values with increased dose of anacardic acid (AA) in the mortadellas $\left(\mathrm{Y}=0.35-0.0007 \mathrm{X}, \mathrm{R}^{2}=0.59, \mathrm{p}\right.$-value $\left.<0.0001\right)$ demonstrating dose-dependent AA.

Qi \& Zhou (2013) evaluated the antioxidant effect of a lotus seed epicarp extract in growing concentrations in pork homogenates representative of Chinese Cantonese Sausage using TBARS. These authors also reported that the lotus seed epicarp extract significantly retarded the level of lipid oxidation in a dose-dependent manner.

Doménech-Asensi et al. (2013), in turn, evaluated the effect of the addition of tomato paste to sausage mortadella in order to reduce the lipid oxidation associated with the content of lycopene. These authors observed that all mortadella formulations of tomato paste (2, 6 and 10\%) had lower TBARS values when compared with the regular mortadella sample. However, no significant differences were observed between the three concentrations of tomato paste.
The antioxidant effect of AA is due to the phenolic feature. Lee \& Shibamoto (2002) reported that phenolic compounds found in plants act as radical scavengers and, sometimes, as metal chelating, acting in the initiation step and the in propagation step of the oxidative process.

Studies with natural antioxidants containing phenolic compounds have shown their efficiency in the lipid oxidation reduction of meat products. Pereira et al. (2010) reported that mango bark extract was effective in delaying lipid oxidation in the mortadellas when doses up to $2000 \mathrm{ppm}$ were used. Banerjee et al. (2012), in turn, using broccoli extract at concentrations from 10000 to $20000 \mathrm{ppm}$ in the goat meat nuggets observed a decrease in TBARS values with higher levels of extract.

Viuda-Martos et al. (2010), adding rosemary essential oil (200 ppm) and different concentrations of citrus fiber washing water (50000-100000 ppm) obtained as a co-product during the extraction of dietary fiber from citrus co-products observed a significant reduction in the TBARS values of bologna sausages when compared with control samples. The samples containing rosemary essential oil and 50000 ppm of citrus fiber washing water, and those containing rosemary essential oil and $100000 \mathrm{ppm}$ of citrus fiber washing water provided reduction of $6.56 \%$ and $8.14 \%$ in the TBARS values, respectively. In the present study, higher reduction was obtained from 100 ppm of AA (14.71\%), reaching a reduction of $44.11 \%$ with $200 \mathrm{ppm}$ of this antioxidant.

According to the means test (Table 2), BHT addition (100 ppm), 100, 150 and 200 ppm AA, provided lower TBARS values when compared to those obtained for the control group. The mortadella samples containing 150 and 200 ppm of AA had TBARS values lower than those of BHT treatment (100 ppm). The 200 ppm AA addition provided the lower TBARS values among all treatments evaluated.

It is important to emphasize that in the present study, the addition of AA at $100 \mathrm{ppm}$ dose had similar effect in the lipid oxidation reduction than the synthetic antioxidant BHT (100 ppm), at the same concentration. Other researches have shown that

Table 2. Thiobarbituric acid-reactive substances values (mg MDA. $\mathrm{kg}^{-1}$ sample) of mortadellas added of butylated hydroxytoluene (BHT) or anacardic acid (AA) and stored at $4{ }^{\circ} \mathrm{C}$ for 90 days.

\begin{tabular}{|c|c|c|c|c|c|}
\hline \multirow{2}{*}{ Treatments } & \multicolumn{5}{|c|}{ Storage time (days) } \\
\hline & 0 & 30 & 60 & 90 & Mean \\
\hline without antioxidant & $0.38 \pm 0.01$ & $0.35 \pm 0.01$ & $0.33 \pm 0.04$ & $0.31 \pm 0.02$ & $0.34 \pm 0.03 \mathrm{a}$ \\
\hline 100 ppm BHT & $0.27 \pm 0.02$ & $0.31 \pm 0.03$ & $0.31 \pm 0.03$ & $0.31 \pm 0.08$ & $0.30 \pm 0.02 b$ \\
\hline 50 ppm AA & $0.31 \pm 0.01$ & $0.33 \pm 0.03$ & $0.30 \pm 0.02$ & $0.32 \pm 0.11$ & $0.2 \pm 0.01 \mathrm{ab}$ \\
\hline $100 \mathrm{ppm} \mathrm{AA}$ & $0.29 \pm 0.08$ & $0.28 \pm 0.01$ & $0.30 \pm 0.04$ & $0.28 \pm 0.02$ & $0.29 \pm 0.01 \mathrm{bc}$ \\
\hline $150 \mathrm{ppm} \mathrm{AA}$ & $0.25 \pm 0.03$ & $0.25 \pm 0.03$ & $0.25 \pm 0.01$ & $0.30 \pm 0.01$ & $0.26 \pm 0.02 c$ \\
\hline $200 \mathrm{ppm} \mathrm{AA}$ & $0.17 \pm 0.07$ & $0.18 \pm 0.05$ & $0.20 \pm 0.02$ & $0.20 \pm 0.04$ & $0.19 \pm 0.02 \mathrm{~d}$ \\
\hline Mean & $0.28 \pm 0.07$ & $0.28 \pm 0.06$ & $0.28 \pm 0.05$ & $0.29 \pm 0.04$ & \\
\hline ANOVA effects & & & $p$-Value & & \\
\hline Treatment & & & $<0.0001$ & & \\
\hline Time & & & 0.8426 & & \\
\hline Treatment $\mathrm{x}$ time & & & 0.2179 & & \\
\hline $\mathrm{CV}(\%)$ & & & 15.15 & & \\
\hline
\end{tabular}


higher doses of natural antioxidants are necessary to have the same effect of the synthetic antioxidant. Jayawardana et al. (2011), evaluating the antioxidant effect of commercial adzuki bean extract in the uncured cooked pork sausages, obtained equal effectiveness when doses 2 folds higher were used. Berasategi et al. (2011), comparing the effectiveness of butylhydroxy anisole synthetic antioxidant with a lyophilized aqueous ethanolic extract of Melissa officinalis added in the bologna-type mortadella reported that natural antioxidant was equally effective to synthetic antioxidant in inhibiting lipid oxidation up to 5 folds higher.

\subsection{Evaluation of color parameters during shelf-life storage}

In this study, there was no significant interaction $(\mathrm{p}>0.05)$ between treatments and storage times of mortadellas for color parameters $\mathrm{a}^{\star}, \mathrm{L}^{\star}$ and $\mathrm{b}^{\star}$ (Tables 3,4 and 5). According to the regression analysis, color component $\mathrm{a}^{*}$ (redness) decreased over time storage $\left(\mathrm{Y}=12.05-0.01 \mathrm{X}, \mathrm{R}^{2}=0.32\right.$, $\mathrm{p}$-value $\left.<0.0001\right)$ and did not vary significantly $(\mathrm{p}>0.05)$ with the increase of anacardic acid dose in the mortadellas. According to the means test, mortadella samples containing $200 \mathrm{ppm}$ of AA had lower redness when compared to others treatments (Table 3).
The redness is the most important color parameter in evaluating of meat and meat products. The redness reduction may indicate a discoloration of meat product making it unacceptable to consumers (Kim et al., 2013). Several authors have reported a reduction of redness with the use of natural antioxidants, and attributed this reduction to several factors.

Kulkarni et al. (2011), adding grape seed extract antioxidant in sausage observed that after 120 days of storage there was a reduction in the redness. According to authors, this decrease is due to interaction of the pigments with the products of lipid oxidation. Mitsumoto et al. (2005) reported a discoloration in cooked beef and chicken meat patties when tea catechins (200 or $400 \mathrm{ppm}$ ) were added. The authors attributed this discoloration to binding with the iron component of myoglobin. Oliveira et al. (2012) also reported a reduction in the redness in the mortadella-type sausages when Satureja montana L. essential oil was added. According to authors, the reduction in the redness can be explained by a possible interaction between nitrite and chemical components present in the antioxidant, making the nitrite unavailable to combine with myoglobin to produce the characteristic red color. Therefore, the reduction in the redness

Table 3. Color component $\mathrm{a}^{\star}$ of mortadellas added of butylated hydroxytoluene (BHT) or anacardic acid (AA) and stored at $4{ }^{\circ} \mathrm{C}$ for 90 days.

\begin{tabular}{|c|c|c|c|c|c|}
\hline \multirow{2}{*}{ Treatments } & \multicolumn{5}{|c|}{ Storage time (days) } \\
\hline & 0 & 30 & 60 & 90 & Mean \\
\hline without antioxidant & $12.07 \pm 0.74$ & $11.92 \pm 0.37$ & $11.76 \pm 0.43$ & $11.47 \pm 0.15$ & $11.81 \pm 0.26 \mathrm{a}$ \\
\hline 100 ppm BHT & $11.65 \pm 0.44$ & $11.53 \pm 0.26$ & $11.42 \pm 0.61$ & $11.17 \pm 0.85$ & $11.44 \pm 0.20 \mathrm{a}$ \\
\hline $50 \mathrm{ppm} \mathrm{AA}$ & $12.40 \pm 0.14$ & $11.90 \pm 0.31$ & $11.66 \pm 0.27$ & $10.68 \pm 0.95$ & $11.66 \pm 0.72 \mathrm{a}$ \\
\hline $100 \mathrm{ppm} \mathrm{AA}$ & $12.02 \pm 0.31$ & $11.70 \pm 0.29$ & $11.48 \pm 0.43$ & $11.32 \pm 0.31$ & $11.63 \pm 0.30 \mathrm{a}$ \\
\hline $150 \mathrm{ppm} \mathrm{AA}$ & $12.22 \pm 0.36$ & $11.73 \pm 0.38$ & $11.53 \pm 0.40$ & $11.25 \pm 0.26$ & $11.68 \pm 0.41 \mathrm{a}$ \\
\hline ANOVA effects & & & $p$-Value & & \\
\hline Treatment & & & 0.0006 & & \\
\hline Time & & & $<0.0001$ & & \\
\hline Treatment $\mathrm{x}$ time & & & 0.3248 & & \\
\hline CV (\%) & & & 4.30 & & \\
\hline
\end{tabular}

Table 4. Color component $\mathrm{L}^{\star}$ of mortadellas added of butylated hydroxytoluene (BHT) or anacardic acid (AA) and stored at $4{ }^{\circ} \mathrm{C}$ for 90 days.

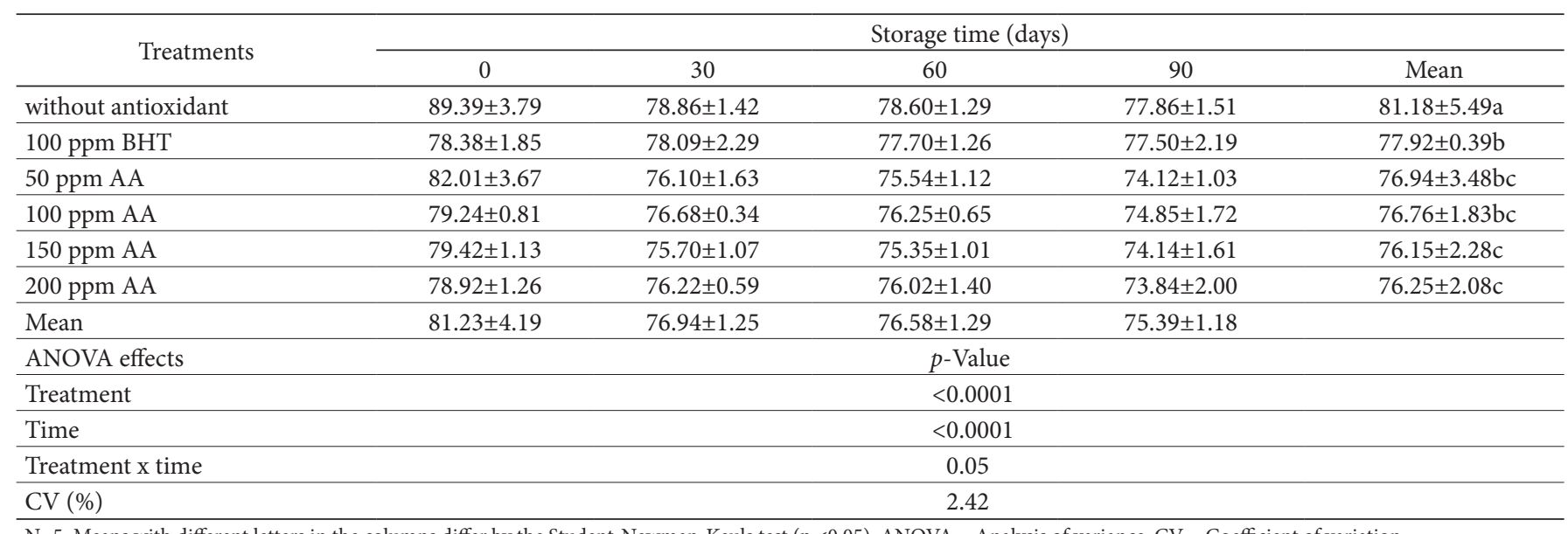

$\mathrm{N}=5$; Means with different letters in the columns differ by the Student-Newman-Keuls test $(\mathrm{p}<0.05)$; ANOVA $=$ Analysis of variance; $\mathrm{CV}=$ Coefficient of variation. 
Table 5. Color component $\mathrm{b}^{*}$ of mortadellas added of butylated hydroxytoluene (BHT) or anacardic acid (AA) and stored at $4{ }^{\circ} \mathrm{C}$ for 90 days.

\begin{tabular}{|c|c|c|c|c|c|}
\hline \multirow{2}{*}{ Treatments } & \multicolumn{5}{|c|}{ Storage time (days) } \\
\hline & 0 & 30 & 60 & 90 & Mean \\
\hline without antioxidant & $14.52 \pm 0.35$ & $14.63 \pm 0.42$ & $14.79 \pm 0.53$ & $15.01 \pm 0.59$ & $14.74 \pm .21 \mathrm{a}$ \\
\hline 100 ppm BHT & $14.03 \pm 0.72$ & $14.54 \pm 0.56$ & $14.55 \pm 0.29$ & $14.86 \pm 0.43$ & $14.50 \pm 0.34 \mathrm{a}$ \\
\hline 100 ppm AA & $14.42 \pm 0.35$ & $14.50 \pm 0.43$ & $14.56 \pm 0.19$ & $14.75 \pm 0.50$ & $14.56 \pm 0.14 \mathrm{a}$ \\
\hline $150 \mathrm{ppm} \mathrm{AA}$ & $14.43 \pm 0.17$ & $14.52 \pm 0.24$ & $14.62 \pm 0.20$ & $14.71 \pm 0.41$ & $14.57 \pm 0.12 \mathrm{a}$ \\
\hline ANOVA effects & \multicolumn{5}{|c|}{$p$-Value } \\
\hline Treatment & \multicolumn{5}{|c|}{0.2690} \\
\hline Time & \multicolumn{5}{|c|}{0.0011} \\
\hline Treatment $\mathrm{x}$ time & \multicolumn{5}{|c|}{0.9942} \\
\hline CV (\%) & \multicolumn{5}{|c|}{2.72} \\
\hline
\end{tabular}

obtained in the present study with $200 \mathrm{ppm}$ of AA may be due to interactions of $\mathrm{AA}$ and the compounds responsible for the color of mortadellas.

Although instrumental redness of products decreases at higher level of antioxidant extracts, differences in sensory evaluation are not always perceived. Banerjee et al. (2012), adding antioxidant extract of broccoli powder in goat meat nuggets, reported a reduction of $4.9 \%$ in the color component $\mathrm{a}^{\star}$ when compared with control treatment. The authors observed that although instrumental redness of nuggets containing broccoli powder has decreased, upon sensory evaluation no difference was perceived. Therefore, the reduction obtained in the present study for treatment with $200 \mathrm{ppm}$ of AA (5.8\%), when compared with control treatment is similar to the value obtained by these authors. Hence, the reduction obtained in the present study would probably not be detected by consumers.

Regarding the color component $\mathrm{L}^{\star}$ (lightness), according to the regression analysis, it has decreased over time storage $\left(\mathrm{Y}=79.40-0.05 \mathrm{X}, \mathrm{R}^{2}=0.35\right.$, $\mathrm{p}$-value $\left.<0.0001\right)$ and did not vary significantly ( $p>0.05)$ with the increase of anacardic acid dose in the mortadellas. According to the means test, mortadella samples containing antioxidants (100 ppm of BHT and 50, 100, 150 or $200 \mathrm{ppm}$ of AA) had lower lightness when compared with control treatment (Table 4).

The increase in lightness is indicative of a pale meat product, which is perceived by the consumer as a negative factor. Therefore, the lower $\mathrm{L}^{*}$ values obtained with addition of AA, compared to control, showed a preservative effect.

Other authors also have reported decreases in the lightness according to natural antioxidants concentration and storage time. Pereira et al. (2011), comparing the addition of mango seed extract (1000 and $2000 \mathrm{ppm}$ ) with BHT (100 ppm) in mortadellas, observed lower values of $\mathrm{L}^{\star}$ with the natural antioxidant. In the present study, lower doses (150 and $200 \mathrm{ppm}$ ) of AA provided lower lightness when compared to control treatment. To storage time, a decrease of lightness with storage time $\left(4^{\circ} \mathrm{C}\right.$ for 15 days $)$ was reported by Bozkurt (2007) using natural antioxidants of sesame and Thymbra spicata oil.
For color component $\mathrm{b}^{*}$ (yellowness), according to the regression analysis, it has increased over time storage $\left(\mathrm{Y}=14.36+0.004 \mathrm{X} ; \mathrm{R}^{2}=0.14 ; p\right.$-value $\left.<0.0001\right)$ and did not vary significantly $(\mathrm{p}>0.05)$ with the increase of anacardic acid dose in the mortadellas. According to the means test, there was no significant difference between the treatments (Table 5).

Increase of yellowness and reduction of redness are related to a discoloration of the meat product, which is not appreciated by the consumer. Aksu \& Kaya (2005) reported an increased in the yelowness of kavurma, a cooked meat product when evaluating the effect of $a$-tocopherol and butylated hydroxyanisole on the colour. The authors observed an increase of $13.68 \%$ in the kavurma yellowness with 90 days of storage at $4{ }^{\circ} \mathrm{C}$. In the present study, just a small increase $(2.93 \%)$ was obtained in the mortadellas with 90 days at $4{ }^{\circ} \mathrm{C}$.

\section{Conclusion}

The results of this study suggest that anacardic acid, in the dose of $200 \mathrm{ppm}$, is a potential natural antioxidant for addition to chicken mortadellas stored for up to 90 days at $4{ }^{\circ} \mathrm{C}$.

\section{Acknowledgements}

The Cearense Foundation for Scientific and Technological Development (FUNCAP) for the financial support.

\section{References}

Abreu, V. K. G., Pereira, A. L. F., Freitas, E. R., Trevisan, M. T. S., \& Costa, J. M. C. (2014). Effect of anacardic acid on oxidative and color stability of spray dried egg yolk. LWT - Food Science and Technology, 55(2), 466-471. http://dx.doi.org/10.1016/j.lwt.2013.10.006.

Aksu, M. I., \& Kaya, M. (2005). The effect of $\alpha$-tocopherol and butylated hydroxyanisole on the colour properties and lipid oxidation of kavurma, a cooked meat product. Meat Science, 71(2), 277-283. http://dx.doi.org/10.1016/j.meatsci.2005.03.023. PMid:22064226.

Banerjee, R., Verma, A. K., Das, A. K., Rajkumar, V., Shewalkar, A. A., \& Narkhede, H. P. (2012). Antioxidant effects of broccoli powder 
extract in goat meat nuggets. Meat Science, 91(2), 179-184. http:// dx.doi.org/10.1016/j.meatsci.2012.01.016. PMid:22330944.

Berasategi, I., Legarra, S., de Ciriano, M. G., Rehecho, S., Calvo, M. I., Cavero, R. Y., Navarro-Blasco, I., Ansorena, D., \& Astiasarán, I. (2011). "High in omega-3 fatty acids" bologna-type sausages stabilized with an aqueous-ethanol extract of Melissa officinalis. Meat Science, 88(4), 705-711. http://dx.doi.org/10.1016/j.meatsci.2011.02.035. PMid:21439735.

Botterweck, A. A. M., Verhagen, H., Goldbohm, R. A., Kleinjans, J., \& van den Brandt, P. A. (2000). Intake of butylated hydroxyanisole and butylated hydroxytoluene and stomach cancer risk: results from analyses in the Netherlands Cohort Study. Food and Chemical Toxicology, 38(7), 599-605. http://dx.doi.org/10.1016/S02786915(00)00042-9. PMid:10942321.

Bozkurt, H. (2007). Comparison of the effects of sesame and Thymbra spicata oil during the manufacturing of Turkish dry fermented sausage. Food Control, 18(2), 149-156. http://dx.doi.org/10.1016/j. foodcont.2005.09.009.

Brasil. Ministério da Agricultura, Pecuária e Abastecimento. (2000, April 5). Regulamentos técnicos de identidade e qualidade de carne mecanicamente separada, de mortadela, de linguica e de salsicha (Instrução Normativa n. 4, de 31 de marco de 2000). Diário Oficial [da] República Federativa do Brasil.

Carvalho, A. L. N., Annoni, R., Silva, P. R. P., Borelli, P., Fock, R. A., Trevisan, M. T. S., \& Mauad, T. (2011). Acute, subacute toxicity and mutagenic effects of anacardic acids from cashew (Anacardium occidentale Linn.) in mice. Journal of Ethnopharmacology, 135(3), 730-736. http://dx.doi.org/10.1016/j.jep.2011.04.002. PMid:21511024.

Cherian, G., Selvaraj, R. K., Goeger, M. P., \& Stitt, P. A. (2002). Muscle fatty acid composition and thiobarbituric acid-reactive substances of broilers fed different cultivars of sorghum. Poultry Science, 81(9), 1415-1420. http://dx.doi.org/10.1093/ps/81.9.1415. PMid:12269624.

Correia, S. J., David, J. P., \& David, J. M. (2006). Metabólitos secundários de espécies de anacardiaceae. Quimica Nova, 29(6), 1287-1300. http://dx.doi.org/10.1590/S0100-40422006000600026.

Cruces-Blanco, C., Segura Carretero, A., Merino Boyle, E., \& Fernández Gutiérrez, A. (1999). The use of dansyl chloride in the spectrofluorimetric determination of the synthetic antioxidant butylated hydroxyanisole in foodstuffs. Talanta, 50(5), 1099-1108. http://dx.doi.org/10.1016/S0039-9140(99)00215-5. PMid:18967805.

Doménech-Asensi, G., García-Alonso, F. J., Martínez, E., Santaella, M., Martín-Pozuelo, G., Bravo, S., \& Periago, M. J. (2013). Effect of the addition of tomato paste on the nutritional and sensory properties of mortadella. Meat Science, 93(2), 213-219. http://dx.doi.org/10.1016/j. meatsci.2012.08.021. PMid:22999311.

Hemshekhar, M., Sebastin Santhosh, M., Kemparaju, K., \& Girish, K. S. (2012). Emerging roles of anacardic acid and its derivatives: a pharmacological overview. Basic \& Clinical Pharmacology \& Toxicology, 110(2), 122-132. http://dx.doi.org/10.1111/j.17427843.2011.00833.x. PMid:22103711.

Jayawardana, B. C., Hirano, T., Han, K.-H., Ishii, H., Okada, T., Shibayama, S., Fukushima, M., Sekikawa, M., \& Shimada, K. (2011). Utilization of adzuki bean extract as a natural antioxidant in cured and uncured cooked pork sausages. Meat Science, 89(2), 150-153. http://dx.doi. org/10.1016/j.meatsci.2011.04.005. PMid:21663804.

Kanatt, S. R., Chander, R., \& Sharma, A. (2010). Antioxidant and antimicrobial activity of pomegranate peel extract improves the shelf life of chicken products. International Journal of Food Science \& Technology, 45(2), 216-222. http://dx.doi.org/10.1111/j.13652621.2009.02124.x.
Kim, S. J., Cho, A. R., \& Han, J. (2013). Antioxidant and antimicrobial activities of leafy green vegetable extracts and their applications to meat product preservation. Food Control, 29(1), 112-120. http:// dx.doi.org/10.1016/j.foodcont.2012.05.060.

Kulkarni, S., DeSantos, F. A., Kattamuri, S., Rossi, S. J., \& Brewer, M. S. (2011). Effect of grape seed extract on oxidative, color and sensory stability of a pre-cooked, frozen, re-heated beef sausage model system. Meat Science, 88(1), 139-144. http://dx.doi.org/10.1016/j. meatsci.2010.12.014. PMid:21193269.

Lee, K. G., \& Shibamoto, T. (2002). Determination of antioxidant potential of volatile extracts isolated from various herbs and spices. Journal of Agricultural and Food Chemistry, 50(17), 4947-4952. http://dx.doi.org/10.1021/jf0255681. PMid:12166987.

Lee, S., Faustman, C., Djordjevic, D., Faraji, H., \& Decker, E. A. (2006). Effect of antioxidants on stabilization of meat products fortified with n-3 fatty acids. Meat Science, 72(1), 18-24. http://dx.doi.org/10.1016/j. meatsci.2005.05.022. PMid:22061369.

Mitsumoto, M., O’Grady, M. N., Kerry, J. P., \& Joe Buckley, D. (2005). Addition of tea catechins and vitamin $\mathrm{C}$ on sensory evaluation, colour and lipid stability during chilled storage in cooked or raw beef and chicken patties. Meat Science, 69(4), 773-779. http://dx.doi. org/10.1016/j.meatsci.2004.11.010. PMid:22063156.

Morais, T. C., Pinto, N. B., Carvalho, K. M. M. B., Rios, J. B., Ricardo, N. M. P. S., Trevisan, M. T. S., Rao, V. S., \& Santos, F. A. (2010). Protective effect of anacardic acids from cashew (Anacardium occidentale) on ethanol-induced gastric damage in mice. ChemicoBiological Interactions, 183(1), 264-269. http://dx.doi.org/10.1016/j. cbi.2009.10.008. PMid:19853593.

Oliveira, T. L. C., Carvalho, S. M., Soares, R. A., Andrade, M. A., Cardoso, M. G., Ramos, E. M., \& Piccoli, R. H. (2012). Antioxidant effects of Satureja Montana L. essential oil on TBARS and color of mortadella-type sausages formulated with different levels of sodium nitrite. LWT - Food Science and Techonology, 45(2), 204-212. http:// dx.doi.org/10.1016/j.lwt.2011.09.006.

Paramashivappa, R., Kumar, P. P., Vithayathil, P. J., \& Rao, A. S. (2001). Novel method for isolation of major phenolic constituents from cashew (Anacardium occidentale L.) nut shell liquid. Journal of Agricultural and Food Chemistry, 49(5), 2548-2551. http://dx.doi. org/10.1021/jf001222j. PMid:11368634.

Pereira, A. L. F., Vidal, T. F., Teixeira, M. C., Oliveira, P. F., Vieira, M. M. M., Zapata, J. F. F., Pompeu, R. C. F. F., \& Freitas, E. R. (2010). Estabilidade oxidativa de mortadelas contendo extrato da casca da manga (Mangifera indica L.). Brazilian Journal of Food Technology, 13(4), 293-298. http://dx.doi.org/10.4260/BJFT2010130400039.

Pereira, A. L. F., Vidal, T. F., Teixeira, M. C., Oliveira, P. F., Pompeu, R. C. F. F., Vieira, M. M. M., \& Zapata, J. F. F. (2011). Antioxidant effect of mango seed extract and butylated hydroxytoluene in bologna-type mortadella during storage. Ciência e Tecnologia de Alimentos, 31(1), 130-140. http://dx.doi.org/10.1590/S0101-20612011000100019.

Qi, S., \& Zhou, D. (2013). Lotus seed epicarp extract as potential antioxidant and anti-obesity additive in Chinese Cantonese Sausage. Meat Science, 93(2), 257-262. http://dx.doi.org/10.1016/j. meatsci.2012.09.001. PMid:23010205.

Selani, M. M., Contreras-Castillo, C. J., Shirahigue, L. D., Gallo, C. R., Plata-Oviedo, M., \& Montes-Villanueva, N. D. (2011). Wine industry residues extracts as natural antioxidants in raw and cooked chicken meat during frozen storage. Meat Science, 88(3), 397-403. http://dx.doi.org/10.1016/j.meatsci.2011.01.017. PMid:21342750.

Trevisan, M. T. S., Pfundstein, B., Haubner, R., Würtele, G., Spiegelhalder, B., Bartsch, H., \& Owen, R. W. (2006). Characterization of alkyl phenols in cashew (Anacardium occidentale) products and assay 
of their antioxidant capacity. Food and Chemical Toxicology, 44(2), 188-197. http://dx.doi.org/10.1016/j.fct.2005.06.012. PMid:16095792.

Valencia, I., Ansorena, D., \& Astiasarán, I. (2007). Development of dry fermented sausages rich in docosahexaenoic acid with oil from the microalgae Schizochytrium sp.: influence on nutritional properties, sensorial quality and oxidation stability. Food Chemistry, 104(3), 1087-1096. http://dx.doi.org/10.1016/j.foodchem.2007.01.021.

Viuda-Martos, M., Ruiz-Navajas, Y., Fernandez-Lopez, J., \& PerezAlvarez, J. A. (2010). Effect of adding citrus fibre washing water and rosemary essential oil on the quality characteristics of a bologna sausage. LWT - Food Science and Techonology, 43(6), 958-963. http:// dx.doi.org/10.1016/j.lwt.2010.02.003.

Xiao, S., Zhang, W. G., Lee, E. J., Ma, C. W., \& Ahn, D. U. (2011). Lipid and protein oxidation of chicken breast rolls as affected by dietary oxidation levels and packaging. Journal of Food Science, 76(4), C612-C617. http://dx.doi.org/10.1111/j.1750-3841.2011.02137.x. PMid:22417343. 